\title{
Reflection and lessons learned
}

Citation for published version (APA):

Bastiaens, E., van Merriënboer, J., \& van Tilburg, J. (2017). Reflection and lessons learned. In Researchbased learning: Case studies from Maastricht University (pp. 185-199). Springer. https://doi.org/10.1007/978-3-319-50993-8_14

Document status and date:

Published: 01/01/2017

DOI:

10.1007/978-3-319-50993-8_14

Document Version:

Publisher's PDF, also known as Version of record

Document license:

Taverne

Please check the document version of this publication:

- A submitted manuscript is the version of the article upon submission and before peer-review. There can be important differences between the submitted version and the official published version of record.

People interested in the research are advised to contact the author for the final version of the publication, or visit the DOI to the publisher's website.

- The final author version and the galley proof are versions of the publication after peer review.

- The final published version features the final layout of the paper including the volume, issue and page numbers.

Link to publication

\footnotetext{
General rights rights.

- You may freely distribute the URL identifying the publication in the public portal. please follow below link for the End User Agreement:

www.umlib.nl/taverne-license

Take down policy

If you believe that this document breaches copyright please contact us at:

repository@maastrichtuniversity.nl

providing details and we will investigate your claim.
}

Copyright and moral rights for the publications made accessible in the public portal are retained by the authors and/or other copyright owners and it is a condition of accessing publications that users recognise and abide by the legal requirements associated with these

- Users may download and print one copy of any publication from the public portal for the purpose of private study or research.

- You may not further distribute the material or use it for any profit-making activity or commercial gain

If the publication is distributed under the terms of Article $25 \mathrm{fa}$ of the Dutch Copyright Act, indicated by the "Taverne" license above, 


\title{
Chapter 14 Reflection \& Lessons Learned
}

\section{Ellen Bastiaens, Jeroen van Merriënboer \& Jonathan van Tilburg}

E.T.W. Bastiaens, ellen.bastiaens@maastrichtuniversity.nl, + 3143 3884975; J.G. van Merriënboer, j.vanmerrienboer@maastrichtuniversity.nl, +31 43 3885727; J.H.O. van Tilburg, jonathan.vantilburg@maastrichtuniversity.nl, +31 433881623

\begin{abstract}
In this final chapter we will take a more reflective look at the case studies and the overall Maastricht Research Based Learning (MaRBLe) programme from two different perspectives. First, the case studies will be positioned in the models of Healey and Jenkins (2009), Beckman and Hensel (2009), and Van Merriënboer (1997). Second, general themes will be distilled from the different case studies. Finally, the chapter concludes with a description of general lessons learned and a final thought on the implementation of research-based learning projects.
\end{abstract}

Key words: course evaluation, educational models, problem-based learning, research-based learning, undergraduate research

\section{Introduction}

This book was written with the ambition to share different forms of research-based learning (RBL) implemented in the bachelor's programmes of Maastricht University (UM) over the past five years. The overarching programme was called the Maastricht Research Based Learning programme (MaRBLe). In the first section of the book we introduced a conceptual framework for the concepts inquiry-based learning, problem-based learning (PBL), and RBL. Furthermore, we introduced three models describing approaches of RBL for the further refinement of undergraduate research at UM. The first model by Healey and Jenkins (2009) focuses on the role of the student (active participant or audience) and the scope of the research programme (research content or research processes and problems). The second model by Beckman and Hensel (2009) distinguishes eight continua for further refining the concept of undergraduate research. The third model by Van Merriënboer (1997) focuses on the level of maturity of the students and the level of independence given to them during their research project. In the second section of the book we presented nine case studies, showing different forms of undergraduate 
research in the various programmes of UM. These case studies demonstrated a broad variety of designs for RBL.

In this final chapter we will take a more reflective look at these case studies and at the overall programme from four different perspectives. First, the case studies will be positioned in the models of Healey and Jenkins (2009), Beckman and Hensel (2009), and Van Merriënboer (1997). Second, general themes will be distilled from the different case studies. The chapter will be concluded with a description of general lessons learned and a final thought.

\section{Analysing the Case Studies by Three Models}

In early 2009 at the very start of MaRBLe, the coordinators of the different educational programmes started organising research opportunities for their students. In this first phase three major questions arose:

1. How to fit research opportunities within the scientific discipline or curriculum;

2. what the research projects should be about, and;

3. how the research projects should be organised.

The coordinators found solutions through an intuitive and bottom-up process; they learned by doing and solved all sorts of practical issues as they came along. In the early period there was little room to draw up a more structured approach for undergraduate research. Introducing the models of Healey and Jenkins (2009), Beckman and Hensel (2009), and Van Merriënboer (1997) resulted in - to say the least - a very interesting discussion with the coordinators, because they gave more in-depth insights into how RBL could be designed, and what it means to staff and students. Within MaRBLe, all coordinators showed great creativity, persistence, and courage to implement this programme at their faculties; they were willing to step outside their comfort zone. Similarly, both supervisors and students were more than willing to go that extra mile to create an optimal research experience.

In the end, describing their case studies within the framework of the models turned out to be challenging for most coordinators, as they were provided with the models long after the MaRBLe programme had been implemented. The following sections will discuss a number of highlights for all three models.

\section{The Model of Healey and Jenkins}

Figure 14.1 positions the different cases studies in the model of Healey and Jenkins (Healey \& Jenkins, 2009). 


\begin{tabular}{|c|c|}
\hline $\begin{array}{l}\text { Research-tutored } \\
\text { Curriculum emphasises } \\
\text { learning focused on students } \\
\text { writing and discussing papers } \\
\text { or essays }\end{array}$ & $\begin{array}{l}\text { Research-based } \\
\text { Curriculum emphasises } \\
\text { students undertaking inquiry- } \\
\text { based learning } \\
\text { MSP FPN } \\
\text { SCM FAS } \\
\text { SBE UCM }\end{array}$ \\
\hline $\begin{array}{l}\text { Research-led } \\
\text { Curriculum is structured LAW } \\
\text { around teaching subject } \\
\text { content }\end{array}$ & $\begin{array}{l}\text { Research-oriented } \\
\text { Curriculum emphasises } \\
\text { teaching processes of } \\
\text { knowledge construction }\end{array}$ \\
\hline
\end{tabular}

Fig. 14.1 Programmes positioned within the model of Healey \& Jenkins (2009)

For reasons of readability and transparency, the case studies are placed only in their predominant quarter. The large majority of the case studies can be positioned in the right upper corner of the Healey and Jenkins' model. In these case studies, students conducting research is the central objective. Of course there are some partial exceptions, for instance, the MaRBLe project at the School of Business and Economics (SBE) is divided into three major elements. The first element, the research course as described by Nijhuis (See Chap. 12), can be positioned somewhere between research-based and research-oriented. The second element, writing the capstone, is research-based because students conduct their own research. The third element, the School of Business and Economics-MaRBLe seminar, is research-oriented. At the Faculty of Psychology and Neuroscience (FPN) the entire curriculum is interwoven with research elements, and MaRBLe is the final research project in which students conduct their own research (See Chap. 4). At the Department of Data Science and Knowledge Engineering (DKE), the MaRBLe project can best be described as research-tutored, as students actively read and discuss research papers (See Chap. 11). The Faculty of Law is positioned in the research-led quarter, but is moving towards the research-based learning quarter. In 
the first years, staff at this faculty initiated and structured the research projects (also by presenting the literature to the students), but at this moment projects are increasingly student-initiated and student-driven as students can determine their own research questions (See Chap. 10).

Despite many smaller and larger differences between case studies, they all fit well within the model of Healey and Jenkins (2009). In general, the MaRBLe coordinators found creative solutions for designing and implementing RBL at their faculty and within the existing curriculum. Important for all case studies was creating the most optimal learning opportunity for students within the given context.

\section{The Continua by Beckman and Hensel}

Figure 14.2 positions the different case studies in the model of Beckman and Hensel (2009). For readability and transparency, each case study is positioned on each continuum only once, at what we believed to be the predominant feature. The main choices will be explained for each continuum.

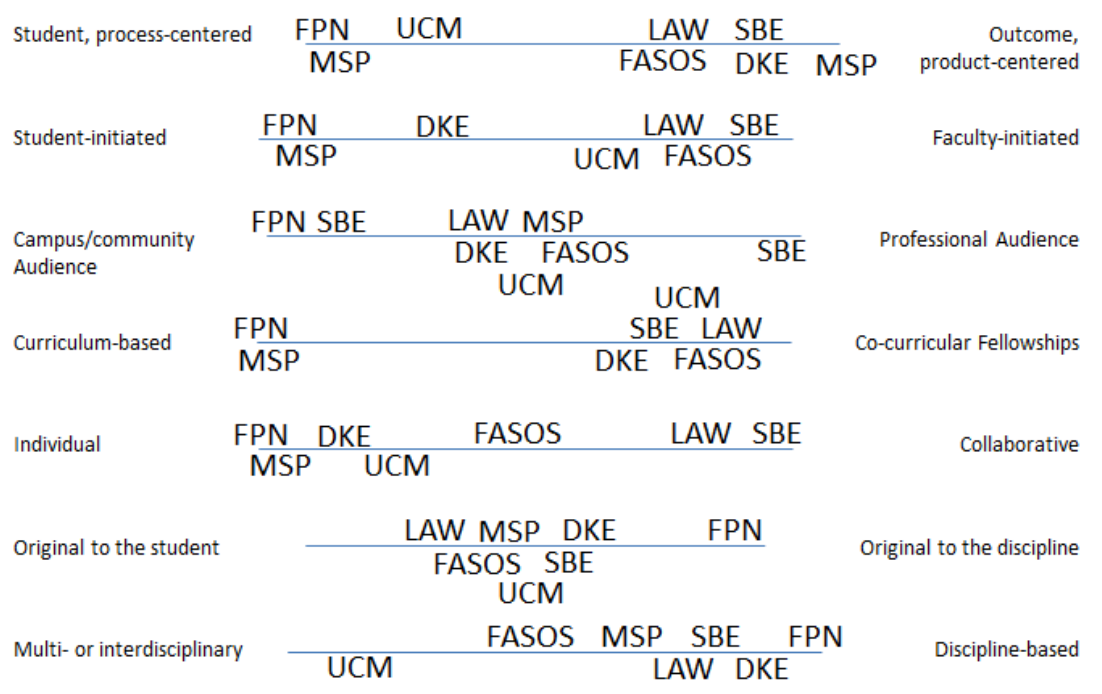

Fig. 14.2 Programmes positioned on Beckman and Hensel's (2009) continua 


\section{Continuum 1: Process-centred - Output-centred}

Looking at the first continuum, the focus is either on the student learning process or on the product delivered by the student. However, FPN expressed very clearly that the research project is both process and product-centred. Students learn by doing research, while at the same time they have to write their bachelor's thesis about their research and are motivated to produce academic work. This double orientation is less explicit for the other faculties and is more or less determined by the way the MaRBLe projects are organised. Within the whole variety of developed programmes, undergraduate research typically contains both process and product-centred elements, although their weight clearly differs. The MaRBLe supervisors play an important role in communicating the specific orientation to their students.

\section{Continuum 2 Student-initiated - Faculty-initiated}

On the continuum student initiated versus faculty initiated, the case studies from FPN, DKE, and the Maastricht Science Programme (MSP; See Chap. 9) are positioned at the utmost left side. In these case studies, students were free to come up with their own research questions and methods for studying those questions within the restrictions of a limited budget and laboratory hours, or a mixture of the two. For the other programmes, the research projects are defined by the supervisors and students are invited to join one of these projects. Within the projects, students have a certain amount of freedom to choose their own research questions. At SBE, the research questions were already defined in some projects, while in other projects students had more freedom of choice. For students it is probably more interesting to initiate a research cycle by defining their own research question, but due to practical and financial limitations this was not always feasible. Nevertheless, facilitating research experience within a pre-determined project can still offer a viable alternative to students.

\section{Continuum 3 Campus Audience - Professional Audience}

FPN and SBE are the only two faculties explicitly aiming at a campus audience: they organise an annual MaRBLe seminar where students have to present their research to their peers and academic staff. At FPN, this seminar is completely based on poster presentations, whereas SBE's seminar is a mixture of poster presentations and short oral presentations. Besides presenting for a faculty audience, the supervisors at these faculties also motivate students to produce academic output, for example, by stimulating them to write and publish a journal article. In the case study On Expedition (See Chap. 6), Homburg and Klijn describe how their students are supported to deliver non-academic output: they receive training in writ- 
ing for Wikipedia and contribute one or two articles to Wikipedia about their research topic (in their case a 16th or 17 th century traveller). By aiming at a professional audience, and by having their article or paper peer-reviewed, students experience the research process as any researcher would. We believe this should be the highest aim for all students participating in an undergraduate research programme, although some students will require sizeable support and guidance to develop the necessary competencies and motivation to write for a professional audience. Faculty staff and fellow students simulating this professional audience can also function as a valuable alternative.

\section{Continuum 4 Curriculum-based - Co-curricular Fellowships}

For two case studies, FPN and MSP, the MaRBLe research project is the final course in a curriculum-based approach. In these programmes, it is the final step in a series of research activities undertaken during the entire curriculum, where students now have the freedom to conduct their academic research in an individual setting. This also holds for DKE, where students participate in research activities in the context of a project-based curriculum. In all other case studies, the MaRBLe research project in the third year of the bachelor's programme is typically the first time students encounter a real research project. Some supervisors expected a rather high level of independency from their students, because they were used to working with PBL which is strongly student-centred. Yet, teachers sometimes had to give more support and guidance than they expected beforehand, probably because doing research was new to many of their students.

\section{Continuum 5 Individual - Collaborative}

Three case studies stand out on the continuum of collaborative versus individual research. The case studies of FPN, MSP and DKE describe research projects in which students work individually on their research project. In the other case studies, the research projects have a group character, where students meet on a regular basis with their peer students to discuss progress and their findings. At UM students are used to working in groups with fellow students. For the projects, in which more collaboration is necessary, this can be perceived as an extension of their PBL environment creating a more comfortable or safe environment for the students, whereas in individual projects students have to depend more on their own capabilities. With regard to the effectiveness of either an individual or collaborative approach, the case studies show no clear differences. 


\section{Continuum 6 New Insight for the Student - New Insight for the Discipline}

In all case studies the research projects aim to realise and bring new insights to the discipline. The case study of FPN shows that MaRBLe research projects initially aimed at students discovering new insights. Students can come up with their own research project, questions, and design, and are challenged to push themselves beyond the borders of what they already master. In many individual cases, students succeeded in this and even came up with new insights for their discipline, resulting in scientific output for a professional audience. Focusing on new insights for students places the learning process at a central place, but does certainly not preclude the development of high-quality scientific output.

\section{Continuum 7 Multi-or Interdisciplinary - Mono-discipline}

The seventh continuum describes the dimension multi-disciplinary versus monodisciplinary research. A multidisciplinary approach refers to bringing more than one discipline into one research project. In the reported case studies, students are using insights from other disciplines to some extent in their research, but they typically work in groups with members from the same discipline or bachelor's programme. One of the initial ambitions of MaRBLe was to develop interdisciplinary or even interfaculty research projects. A first example is the research project around the broad concept of Virtuality, aimed at students from three different programmes: humanities, psychology and University College Maastricht (UCM; See Chap. 8), a small-scale college of Liberal Arts and Sciences. Although the individual products of the participating students were innovative and added knowledge within the discipline, it was difficult for students to transfer knowledge to the other disciplines. This was also difficult for the staff involved because they were deeply rooted within their own disciplines and models, finding it hard to escape their own paradigms. The second example is from SBE, which is divided in two main clusters: Business and Economics. The perspectives on research in both clusters are very different. Therefore, SBE is still searching for the best possible way to allow students from both clusters to take the same course by integrating the research models. To summarise, most MaRBLe projects were of a monodisciplinary nature, with the exception of projects focusing on a broader European context as described in Chapter 5 and Chapter 10.

In conclusion, although it was an interesting exercise to analyse all case studies using the continua of Beckman and Hensel (2009), we do not think that the analysis yielded many new insights into the distinct case studies. However, it clearly showed that the RBL projects under the umbrella of MaRBLe are embedded within the UM programmes in a wide variety of designs. The continua could have provided some guidelines for designing research opportunities for bachelor's stu- 
dents, but due to the given structure of these programmes, the coordinators foremost had to look for solutions best fitting their programme.

\section{Four Components Instructional Design (4C/ID) Model}

In this section, it is determined to what extent the different case studies apply design principles from Van Merriënboer's (1997) four-component instructional design model (4C/ID). With regard to design principles related to learning tasks (component 1), it is no surprise that all case studies take one or more real-life research tasks as a starting point. These tasks or research projects are generally formulated in three ways: by the academic staff, as is common practice at FPN and MSP; by external parties, usually at the Faculty of Art and Social Sciences (FASoS) and for some projects at SBE; and by students themselves, often within the context of a broader theme, most commonly at DKE and to some extent at UCM.

For learning tasks, additional design principles relate to variation, meaning that student must work on a broad variety of research projects that are representative for the whole research field. They are: sequencing, indicating that these projects are best sequenced from simple projects to more and more complex projects; available support and guidance (scaffolding), which ideally diminishes as students gain more expertise by their work on the projects. These principles are applied in three case studies: FPN, MSP, and DKE. In these programmes, RBL is implemented as a learning trajectory that is well-integrated into the curriculum. In all other case studies, there is no planned variation over a series of projects and no sequencing from simple to increasingly more complex projects. Furthermore, although support and guidance is given by project supervisors and peers, there is no gradual decrease of provided support and guidance in a process of scaffolding. Thus, in the majority of case studies, MaRBLe is not realised as a learning trajectory but as a stand-alone course or project.

With regard to supportive information (component 2), the three case studies that implemented MaRBLE as part of a learning trajectory clearly linked relevant courses to research projects at different levels of complexity. At FPN and DKE, courses offering supportive information, such as quantitative and qualitative research methods, are organised per academic year and are aligned with the research projects in the same year. In MSP, there is more flexibility, but students received advice from staff on which courses to follow. In all other case studies, the provision of supportive information is more or less integrated in the MaRBLe project itself. Often, students must search for relevant learning resources themselves, which nicely fits the Maastricht PBL-system. 
A similar pattern can be discerned for the presentation of procedural information (component 3 ) and the provision of part-task practice (component 4 ). The three case studies that implemented MaRBLe as a learning trajectory typically predefined and pre-organised the presentation of procedural information by preparing job aids, manuals, and guidelines, and they organised part-task practice in data entry, presentation skills, handling subjects, programming, and others in such a way that it sustained the research projects. In all other case studies, procedural information that students need while they are working on their research project is typically provided by their supervisor when needed. The same is true for part-task practice; it is not pre-defined but organised when the need arises. For instance, in the On Expedition project at FASoS, the writing of Wikis became an important part of the MaRBLe project and it was decided to organise a skills training on how to write Wikis.

In conclusion, it is clear that all case studies use one or more real-life research tasks, which complies with the most basic principle of the 4C/ID model. However, only three case studies entailed a learning trajectory that helps students gradually develop their research skills. In these case studies, a clear distinction can be made between the four components. In all other case studies, the MaRBLe project is a separate activity centred on only one learning task. The three other components are not designed beforehand but flexibly integrated into the project: students must search for relevant learning resources (supportive information), the supervisor provides how-to instructions (procedural information) only when students need it, and particular skills are trained (part-task training) when they are necessary for the specific project at hand.

\section{Conclusions with regards to the Three Models}

In retrospect, the three models gave us a better grasp of the wide variety of RBL opportunities for students and its general set-up at the different faculties. Despite faculty and curriculum restrictions and differences in research disciplines, the MaRBLe coordinators found methods to implement interesting research experiences for their third year bachelor's students. This leaves the intriguing question as to whether it would have been possible to implement RBL at all faculties if the three models were outlined upfront, especially if these models were used as prescriptions or rules-of-thumb for developing research opportunities for third year bachelor's students. We believe that the various forms for RBL arose as a result of dedication and commitment by the coordinators, without the support of educational models. Nevertheless, we also think that most of the MaRBLe projects can be further improved by applying concepts and principles from the three models. 


\section{Reflection on General Themes}

Table 14.1 provides a comparison of the case studies on seven general themes that were addressed in two or more case studies.

Table 14.1 General Themes addressed in Case Studies

\begin{tabular}{|c|c|c|c|c|c|c|c|c|c|}
\hline & $\begin{array}{l}\text { FPN: } \\
\text { Arie van } \\
\text { der Lugt } \\
\text { \& Herco } \\
\text { Fonteijn }\end{array}$ & $\begin{array}{l}\text { FASoS } \\
\text { APieter } \\
\text { tCaljé } \\
\end{array}$ & $\begin{array}{l}\text { :Library } \\
\text { and Jezuit } \\
\text { Collection: } \\
\text { Ernst } \\
\text { Homburg } \\
\& \text { Anne- } \\
\text { miek Klijn }\end{array}$ & $\begin{array}{l}\text { Changing } \\
\text { Research } \\
\text { :Contexts: } \\
\text { Ragna } \\
\text { Zeiss } \\
\end{array}$ & $\begin{array}{l}\text { UCM: } \\
\text { Oscar van } \\
\text { den Wijn- } \\
\text { gaard }\end{array}$ & $\begin{array}{l}\text { MSP: } \\
\text { Thomas } \\
\text { - Cleij \& } \\
\text { Menno } \\
\text { Knetsch }\end{array}$ & $\begin{array}{l}\text { Faculty of } \\
\text { Law: } \\
\text { Bram Ak- } \\
\text { kermans }\end{array}$ & $\begin{array}{l}\text { DKE: } \\
\text { Nico } \\
\text { Roos }\end{array}$ & $\begin{array}{l}\text { SBE: } \\
\text { Jan } \\
\text { Nijhuis }\end{array}$ \\
\hline $\begin{array}{l}\text { Theme } 1 \text { Role } \\
\text { of the Super- } \\
\text { visor }\end{array}$ & & $\mathrm{X}$ & $\mathrm{X}$ & $\mathrm{X}$ & & $X$ & & & \\
\hline $\begin{array}{l}\text { Theme } 2 \\
\text { Community } \\
\text { and Peer Re- } \\
\text { view }\end{array}$ & & $X$ & $\mathrm{X}$ & $\mathrm{X}$ & $\mathrm{X}$ & & $\mathrm{X}$ & & $X$ \\
\hline Theme 3 & $\mathrm{X}$ & $\mathrm{X}$ & $\mathrm{X}$ & $\mathrm{X}$ & $\mathrm{X}$ & $\mathrm{X}$ & $\mathrm{X}$ & $\mathrm{X}$ & $\mathrm{X}$ \\
\hline $\begin{array}{l}\text { Selection Pro- } \\
\text { cedure }\end{array}$ & & & & & & & & & \\
\hline $\begin{array}{l}\text { Theme } 4 \\
\text { Link to Over- } \\
\text { all Pro- } \\
\text { gramme }\end{array}$ & $X$ & & & & & $X$ & & $\mathrm{X}$ & \\
\hline $\begin{array}{l}\text { Theme } 5 \\
\text { Relations to } \\
\text { Outside } \\
\text { World/ Coop- } \\
\text { eration }\end{array}$ & & & & $\mathrm{X}$ & & & & & $\mathrm{X}$ \\
\hline $\begin{array}{l}\text { Theme } 6 \\
\text { Student Em- } \\
\text { powerment }\end{array}$ & & $\mathrm{X}$ & $\mathrm{X}$ & $\mathrm{X}$ & $\mathrm{X}$ & & & & \\
\hline $\begin{array}{l}\text { Theme } 7 \\
\text { Management } \\
\text { and organisa- } \\
\text { tion }\end{array}$ & $X$ & $X$ & $\mathrm{X}$ & $X$ & $\mathrm{X}$ & $X$ & $\mathrm{X}$ & $\mathrm{X}$ & $X$ \\
\hline
\end{tabular}




\section{Theme 1 Role of the Supervisor}

In the context of MaRBLe, supervisors can have different backgrounds in research. For instance, the supervisor is either a $\mathrm{PhD}$ candidate, in which case the students join them in their $\mathrm{PhD}$ research, or the supervisor is a senior researcher, coaching the students' learning process during the research project. In some case studies, the supervisor communicates one-to-one with students, and in other cases the supervisor meets students in group meetings. In all case studies, the supervisor is crucial for optimising the students' learning process. In most case studies, the supervisor acts as a role model, demonstrating how to conduct research. Although role models are powerful in educating students in a certain research approach, the supervisor must also be aware to keep an open eye for alternative research approaches. Moreover, the research-based teacher is increasingly becoming a primus inter pares within a learning community (See Chap. 1).

\section{Theme 2 Community and Peer Review}

Establishing a community of practice is vital to the success of RBL projects (See Chap. 1). Jan Nijhuis introduced SBE's various disciplines in his case study. Students from these different disciplines form a community during the course of the MaRBLe project. In this course they learn about research in other disciplines in the broad field of business and economics, yet they also work on their own monodisciplinary research. In other case studies, the newly formed academic community uses elements of peer review and is organised to structure and optimise the learning process. In general, students perceived the collaboration with other students as highly valuable, especially for discussing research methodologies and common research and writing problems. At FPN, there is hardly any room to create an academic community for students, due to the high level of autonomy that is given to them in defining their own research. At FASoS, an academic community is constantly growing through connecting alumni of former MaRBLe projects to new generations of MaRBLe students. The process of peer reviewing is organised in group meetings, but is in most cases not structured by formal procedures. Supervisors prefer to organise these moments of peer review in an informal setting. Overall, organising an academic community contributes to the success of the MaRBLe projects, because they allow for the optimisation of the individual learning processes of students and the exchange of new insights and perspectives. Peer review can be a valuable part of such an academic research community, but is not strictly necessary. 


\section{Theme 3 Selection Procedure}

For MSP, the selection of students is organised when they enter the bachelor's programme, while in the other case studies selection is based on grades first, and then on motivation. These case studies use an average grade point of 7.5 (on the Dutch 10-point scale) as a minimum entry level. Furthermore, participants must show absence of any study delay in the first two years of their bachelor's programme.

The past years have shown that selection is necessary as not all students have the necessary capabilities and competencies to start and complete a research project. However, motivation seems to be much more important than grades. The intrinsic motivation for conducting academic research stimulates students in a much better way than just high grades, and should therefore be part of any selection procedure.

\section{Theme 4 Link to Overall Programme}

In some faculties research is more embedded within the curriculum than in others. For example, at FPN, the curriculum was redesigned to integrate research into all three years of the bachelor's programme: MaRBLe was brought forward and implemented as a new opportunity to facilitate students in conducting their own research. At MSP, research was integrated in the whole curriculum from the very first start. To a lesser extent this also applies to DKE, where research is embedded into the curriculum by the projects in which students learn to apply their knowledge. At other faculties, for instance the Faculty of Law and FASoS, the MaRBLe project was for many of the students their first experience with research in terms of completing an entire research cycle. Due to their experience with MaRBLe, some supervisors changed their regular courses in order to strengthen their research focus. The interaction between MaRBLe courses and the regular programmes, both at the level of students and at the level of staff, has definitely increased the amount of research in all bachelor's programmes at UM.

\section{Theme 5 Relations to the Outside World}

Initially, MaRBLe was set up as a research experience for students in which they were confronted with authentic research questions from clients, but this proved difficult to implement. However, SBE succeeded in this aim by allowing students to join the Service Science Factory under the umbrella of MaRBLe, and at FASoS where supervisor Ragna Zeiss explicitly chose to set up her research projects with 
an external and formal client (See Chap. 7). This confronted the students, the client, and the supervisor with new challenges as a balance had to be found between the academic level required by MaRBLe and answering the client's often more practical questions. An interesting question is why it is so difficult to define research questions for bachelor's students with external clients. As stated by Ragna Zeiss, this can at least be partly explained by the fact that clients often have other expectancies of output and are to a lesser extent interested in the scientific value of research.

\section{Theme 6 Student Empowerment}

For most students, MaRBLe was the first time they were required to work highly independently. With the start of MaRBLe, the impact of this programme on the university, supervisors, students, and faculty staff could not be foreseen. Empowering students and supporting their projects with good academic and practical support and by offering a stimulating research setting has definitely increased the performance of a vast majority of the MaRBLe students. MaRBLe turned out to be a reality check for both students and supervisors with regard to the level of selfconfidence and autonomy of students. It should be aimed to give students enough freedom whilst empowering them to find their own way. One of the coordinators explicitly asked the question whether it is fair to expect bachelor's students to handle the level of autonomy required by working independently on a research project - perhaps students need more educational structure. This would imply embedding more research into the general curriculum, with MaRBLe as the final step in which a selection of the students would have the opportunity to go through the whole cycle of research at a more independent level.

In RBL models where students are regularly confronted with research throughout the curriculum, as is common practice at FPN, MPS, and to lesser extent DKE, the students can probably handle the degree of independence and autonomy expected by supervisors more easily. As we have seen, the four-component instructional design model (Merriënboer, 1997), offers a set of principles that may help to design such learning trajectories, and examples can be found at FPN, MSP, and DKE. One of the authors of the On Expedition project stated that in his opinion, RBL is the essence of learning to conduct research: "Students carve out their own domains and define their own learning path with regard to research". Thus, he emphasises the importance of students working and learning autonomously. This reflection also criticises PBL as an educational approach. PBL assumes that students learn to work independently and autonomously, but supervisors were confronted with students who had to overcome many (personal) challenges in in order to perform at the required level of autonomy. For students who come into contact with research for the first time during the MaRBLe programme, the required level of 
independence will sometimes be a step too far, even though this is expected by supervisors. Possibly, the Maastricht PBL-system, with its seven-step model and intensive tutor support, insufficiently encourages students' self-directed learning skills. One coordinator noted that a number of UCM students were not keen on their potential research experience due to a lack of self-confidence.

\section{Theme 7 Management and Organisation}

Previously, we have discussed the pioneering roles of the coordinators and supervisors. Facilitating this pioneering work requires that to some extent, the coordinators are supported and sponsored by the management of their organisations. Pioneers need room for experimentation. We learnt that for MaRBLe, a delicate balance between centralised organisation and support on the one hand, and decentralised implementation on the other, was necessary to achieve the programme's goals. Open, transparent and frequent communication is vital to the success of such a project.

Setting up and continuing an open discussion on educational concepts proved to be of vital importance to guard the quality and implementation of RBL within the MaRBLe programme at all faculties. In our particular case, these discussions focused on distinctions between the concepts PBL and RBL, but also on ways to transfer elements of the MaRBLe programme to the broader student community. Continuous dialogue is necessary to optimise both undergraduate research and PBL and other forms of inquiry-based learning.

Using an external stimulus to start developing and implementing a new educational concept can be tricky. In the Netherlands, the Sirius programme (See Chap. 2) for Excellence has definitely given a strong incentive to develop MaRBLe at UM. Most coordinators agree with the statement that without external funding from Sirius, UM would have never developed a programme for RBL as presented in the case studies in this book. Nevertheless, there is also a severe risk involved for the university's management. High-intensive education comes with a price for supervisory hours, but also for conducting field research or reserving hours in a laboratory. This implies that the higher management should decide beforehand whether they are willing to invest in a new educational concept such as RBL, also considering the additional costs during the period after the grant has ended. 


\section{Conclusions with Regards to the General Themes}

Discussing the case studies according to the main themes shows that RBL can be implemented in many different forms. The most vital characteristics are that students are provided with an opportunity to conduct their own academic research, that they can go through the whole research cycle, and that they are given sufficient possibilities to discuss their experiences and academic output with academic staff and fellow students.

\section{Lessons Learned}

This book presented nine case studies and one evaluation chapter as the sum of five years of experience with different designs for undergraduate research. The case studies implemented RBL in different ways, into different disciplines and in different styles. Five years and nine case studies taught us some general overarching lessons learned which are presented in the overview below.

Vital elements to successfully establishing RBL projects are:

- Continuous dialogue between students and supervisors;

- facilitating dialogue between faculties to exchange experiences and best practices;

- establishing a community of practice;

- scaffolding and sequencing in order to facilitate the transition from PBL to RBL;

- empowering students in the development of academic research skills;

- encouraging and supporting the faculties throughout their journey;

- realizing that selection is necessary and intrinsic motivation may be just as important as grades;

- external stakeholders/audiences motivate students to succeed;

- making use of external opportunities to initiate innovation;

- peer reviewing to motivate students to meet their deadlines.

\section{The Journey Continues}

Some coordinators used the metaphor of a journey for their quest to implement an educational approach providing bachelor's students with authentic research experiences. Writing this book was a journey for the editors and the authors. It was a journey to write the chapters on the different case studies, but definitely and more 
importantly, to be involved in an ongoing discussion about the essence of PBL and RBL, the role of the supervisor, and the value of working with external clients. This journey does not end here; UM will keep on improving RBL for bachelor's students. The recently published Strategic Agenda Higher Education 2015-2025, the Value(s) of Knowing (Ministry of Education, Culture and Science, 2015) pleas for the further integration of research and education. Involving students in academic research or having students conduct their own research stimulates creative and innovative interactions between students and staff, eventually leading to new research questions and new insights for the discipline (p.28). Maastricht University's strategic programme for the period 2017-2021 Community at the CORE, strongly emphasises the CORE-concept: Collaborative Open Education Research. In CORE-labs researches and students, preferably from multiple disciplines, closely collaborate on pressing societal issues (Maastricht University, 2016).

We sincerely hope this book will offer institutions for higher education inspiration for their own journey into the world of RBL.

\section{References}

Beckman, M., \& Hensel, N. (2009). Making explicit the implicit: Defining undergraduate research. CUR Quarterly, 29(4), 40-44.

Healey, M., \& Jenkins, A. (2009). Developing undergraduate research and inquiry. York: Higher Education Academy.

Maastricht University (2016). Community at the CORE. Strategic Programme 2017-2021.

Merriënboer, J. J. G. van (1997). Training complex cognitive skills: A four-component instructional design model for technical training. Englewood Cliffs, NJ: Educational Technology Publications.

Merriënboer, J. J. G. van, \& Kirschner, P. A. (2013). Ten steps to complex learning: A systematic approach to four-component instructional design. Abingdon: Routledge.

Ministry of Education, Culture and Science (2015). The value of knowledge Strategic Agenda for Higher Education and Research 2015-2025. The Hague: Directorate of Higher Education and Student Grants. 